\title{
Skyggebilleder? - Nogle kommentarer til validitetsdiskussionen omkring Søren Risbjerg Thomsens metode til økologisk inferens
}

\author{
Indledning \\ Søren Risbjerg Thomsen har med sin afhandling Danish Elections 1920-79. A Lo- \\ git Approach to Ecological Analysis and Inference givet et nyt bud på løsningen af \\ et problem, som mange har anset for uløseligt. Litteraturen, såvel den generelt \\ metodiske som den mere specielle litteratur om vælgeradfærd, har, ikke mindst \\ $\mathrm{i}$ årtierne lige efter fremkomsten af Robinsons klassiske artikel (1950), indeholdt \\ mange advarsler til den, der måtte være formastelig nok til at ville gøre noget ved \\ problemet. Tidligere forsøg på at foretage økologisk inferens ved hjælp af regres- \\ sionsmetoder har ikke haft let ved at finde tilhængere, men er alle blevet kritise- \\ ret. Risbjerg Thomsen er såmænd heller ikke selv for blid ved sine forgængere på \\ dette felt. \\ I dansk vælgeradfærdsforskning gav det uopfyldte ønske om at sige noget gyl- \\ digt om individuelle vælgeres adfærd ud fra valgstatistikkens aggregerede data \\ engang i 1960erne anledning til en nærmest traumatisk metodestrid (Lassen, \\ 1967, 1968; Pedersen, 1967; jfr. også Borre \& Stehouwer, 1970, samt Noack, \\ 1981). Der er dog nu løbet sả meget vand i stranden, at Risbjerg Thomsen med \\ god ret ikke graver i historien, men foretrækker at give en koncis redegørelse for \\ og kritik af tidligere internationale forsøg på at løse den økologiske inferens' pro- \\ blem - hvorefter han koncentrerer sig om at give sit eget bud. \\ Den foreliggende afhandling er således udtryk for en dristig satsning, men dog \\ næppe en dumdristig sảdan. Den opsigt, som metoden allerede har vakt blandt \\ europæiske valgforskere, har sikret Risbjerg Thomsen en placering. Han vil helt \\ givet ryge langt op på SSCI's rangorden over citerede forskere. Om bogen vil \\ "blive stảende", og om den foreslảede metode vil vise sig holdbar og anvendelig, \\ kan man i dag ikke sige noget bestemt om. Det vil, som tilfældet altid er med \\ egentlige nybrud, vise sig efter en længere periode, hvor den internationale, $\mathrm{i}$ \\ dette tilfælde sikkert ganske kritiske, forskerverden har haft lejlighed til at efter- \\ prøve og forsøge falsificering. Men det er væsentligt at fă sagt, at afhandlingens \\ videnskabelige værdi ikke aldeles afhænger af resultatet af denne efterprøvning: \\ bogen skal nok blive stående i kraft af sine egne kvaliteter. Det er kun spørgsmålet \\ om den videnskabelige berømmelses størrelse og varighed, der må vente på afkla- \\ ring.
}




\title{
Skyggebilleder? - Nogle kommentarer til validitetsdiskussionen omkring Søren Risbjerg Thomsens metode til økologisk inferens
}

\author{
Indledning \\ Søren Risbjerg Thomsen har med sin afhandling Danish Elections 1920-79. A Lo- \\ git Approach to Ecological Analysis and Inference givet et nyt bud på løsningen af \\ et problem, som mange har anset for uløseligt. Litteraturen, såvel den generelt \\ metodiske som den mere specielle litteratur om vælgeradfærd, har, ikke mindst \\ $\mathrm{i}$ årtierne lige efter fremkomsten af Robinsons klassiske artikel (1950), indeholdt \\ mange advarsler til den, der måtte være formastelig nok til at ville gøre noget ved \\ problemet. Tidligere forsøg på at foretage økologisk inferens ved hjælp af regres- \\ sionsmetoder har ikke haft let ved at finde tilhængere, men er alle blevet kritise- \\ ret. Risbjerg Thomsen er såmænd heller ikke selv for blid ved sine forgængere på \\ dette felt. \\ I dansk vælgeradfærdsforskning gav det uopfyldte ønske om at sige noget gyl- \\ digt om individuelle vælgeres adfærd ud fra valgstatistikkens aggregerede data \\ engang i 1960erne anledning til en nærmest traumatisk metodestrid (Lassen, \\ 1967, 1968; Pedersen, 1967; jfr. også Borre \& Stehouwer, 1970, samt Noack, \\ 1981). Der er dog nu løbet sả meget vand i stranden, at Risbjerg Thomsen med \\ god ret ikke graver i historien, men foretrækker at give en koncis redegørelse for \\ og kritik af tidligere internationale forsøg på at løse den økologiske inferens' pro- \\ blem - hvorefter han koncentrerer sig om at give sit eget bud. \\ Den foreliggende afhandling er således udtryk for en dristig satsning, men dog \\ næppe en dumdristig sảdan. Den opsigt, som metoden allerede har vakt blandt \\ europæiske valgforskere, har sikret Risbjerg Thomsen en placering. Han vil helt \\ givet ryge langt op på SSCI's rangorden over citerede forskere. Om bogen vil \\ "blive stảende", og om den foreslảede metode vil vise sig holdbar og anvendelig, \\ kan man i dag ikke sige noget bestemt om. Det vil, som tilfældet altid er med \\ egentlige nybrud, vise sig efter en længere periode, hvor den internationale, $\mathrm{i}$ \\ dette tilfælde sikkert ganske kritiske, forskerverden har haft lejlighed til at efter- \\ prøve og forsøge falsificering. Men det er væsentligt at fă sagt, at afhandlingens \\ videnskabelige værdi ikke aldeles afhænger af resultatet af denne efterprøvning: \\ bogen skal nok blive stående i kraft af sine egne kvaliteter. Det er kun spørgsmålet \\ om den videnskabelige berømmelses størrelse og varighed, der må vente på afkla- \\ ring.
}


Så mange positive ord til indledning. Nu til nogle af de problemer og "hvis«er, der knytter sig til metoden, og som må drøftes mere indgående, end Risbjerg Thomsen selv har gjort det. På den til rådighed stående plads er jeg tvunget til at koncentrere diskussionen om Risbjerg Thomsens økologiske estimation af vælgerbevægelser og stabilitet, men de fremførte synspunkter vil også være relevante for resten af de foretagne estimationer.

\section{Bogens primære svaghed: validitetsdrøftelsen}

Når der kan herske en del usikkerhed om metodens bæredygtighed, hænger det primært sammen med, at forfatteren ikke har lagt særlig megen vægt på at underbygge sine resultater med en virkelig grundig diskussion af validiteten. Det bør man måske ikke bebrejde ham, - blandt andet også fordi problematikken i dette tilfælde er særdeles kompleks. Her må jeg nøjes med nogle fả antydninger.

Lad os først se pả det, der ofte kaldes intern validitet, dvs. spørgsmảlet om det logiske forhold mellem det "målte « og det, der skal "måles " (Zetterberg, 1965: 115). Den, der ønsker at foretage økologisk inferens i forbindelse med politiske valg, har en ambitiøs idé om at efterspore og forhåbentlig udfinde de bevægelser, der på valgdagen finder sted i vælgerskaren. Midlet bestär i at manipulere den proces-producerede, aggregerede valgstatistik. $\mathrm{Nu}$ forholder det sig uheldigvis således, at kun en altseende og altvidende tilskuer til valget vil være i stand til at kende "sandheden", således som den udfolder sig. Derfor har det egentlig ingen mening at tale om intern validitet i dette tilfælde, for de statistiske og matematiske konstruktioner, som Risbjerg Thomsen baserer sine forudsigelser på, har intet at gøre med den del af virkeligheden, som vi kalder "et valg «. Det nærmeste man kan komme til en diskussion af dette aspekt er den diskussion, som en statistiker kan foretage af den logiske konsistens i de foretagne ræsonnementer, deres forhold til tidligere fremførte teoremer etc. Da metoden i dette tilfælde ret beset er en generel statistisk metode til behandling af binære og multiple valgsituationer og ikke en metode, der specielt og/eller alene er relateret til politiske valgsituationer, kunne man ovenikøbet forestille sig, at statistikeren ville finde metoden fortræffelig ud fra sine generelle forudsætninger, mens vælgeradfærdsforskeren stadig ville lede - forgæves - efter en isomorfi mellem metodens præmisser og den "virkelighed ", han har specialiseret sig i at forstå.

Sả er der mere ræson i at afprøve Risbjerg Thomsens metode til økologisk inferens ved at undersøge den eksterne validitet. Der findes ovenikøbet de forskere, der vil blæse på den interne konsistens i en model og på dens præmissers realisme, så længe blot modellen giver gode forudsigelser. "Theoretical models should be tested primarily by the accuracy of their predictions rather than by the reality of their assumptions «, hævdede Anthony Downs (1957:21), og han kunne endda støtte sig til Milton Friedman (1953).

Fremgangsmåde i den af Risbjerg Thomsen foretagne validitetstest går blandt andet ud på at sammenligne de forudsigelser, der i en konkret situation - omkring 1973-valget - kan foretages ved hjælp af den nye metode, med andre forudsigelser af vælgernes bevægelser. Overfladisk betragtet virker en sảdan validitetsdiskussion ganske rimelig. Her er vi jo på empirisk grund. I sandhedens interesse 
må vi dog hellere gøre os klart, at man ved at følge Risbjerg Thomsens ræsonnement i realiteten sætter sig i samme situation som den, huleboerne i Platons lignelse befandt sig i, når de sad og sammenlignede skyggebilleder med hinanden. Ideen $\mathrm{i}$ bogens validitetstest er nemlig den, at en rimelig overensstemmelse mellem værdierne i en økologisk estimeret vælgervandringsmatrice og to surveybaserede matricer opfattes som givende støtte til de inferens-baserede resultater.

Da imidlertid udnyttelsen af de to survey-baserede matricer i sig selv er forbundet med alvorlige validitetsproblemer - og ovenikøbet med betydeligt alvorligere problemer, end Risbjerg Thomsen synes at være opmærksom på - fär denne validitetstest i nogen grad karakter af skyggeboksning, eller - for nu at blive i den platonske allegoris sprog - sammenligning af fordrejede skyggebilleder.

Lad mig kort begrunde denne grausame salbe. For det første mả det konstateres, at Risbjerg Thomsen som det ene af sine sammenligningsmaterialer har valgt at benytte en vælgervandringsmatrice, der hidrører fra den store "akademiske" vælgerundersøgelse, nærmere bestemt relaterer sig til valgene 1971 og 1973. Just denne matrice er nok den svagest funderede af dem, der kunne være blevet brugt. Det er velkendt, at man i 1971-undersøgelsens 2. runde kun opnåede en besvarelse fra 62 pct. af de 2114 udtrukne, samt at man i 1973 havde endnu mindre held med sig, idet man da kun opnảede 533 svar, hvilket udgjorde beskedne 41 pct. af de i 1971 interviewede, (Worre, 1976b: 254) - og dermed kun 25 pct. af den oprindelige stikprøve. En sammenligning baseret på et så svagt materiale ville jeg ikke fæste megen lid til. En passant kan peges på, at når Risbjerg Thomsen har valgt at slå ned på data fra perioden 1971-73, kan det tænkes at hænge sammen med, at der her var tale om et panelstudie, og panelstudier opfattes jo oftest som bedre kilder end surveyspørgsmål med recall-karakter. Men udgør recallproblematikken en større trussel mod validiteten end en ussel besvarelsesprocent? Nyere resultater fra såvel Holland (Eijk \& Niemüller, 1983) som Danmark (Hansen, 1987) peger i retning af, at man ikke skal være så bange for at benytte recall-oplysninger. Min konklusion på dette punkt er, at Risbjerg Thomsen hellere skulle have baseret sin validitetstest på undersøgelserne fra de senere valg i 1970erne, hvor partisystem-forholdene også var mere "normale ".

Dernæst må det konstateres, at brugen af OBSERVA-materialerne heller ikke er uproblematisk. Her tænker jeg naturligvis ikke på, at der senere af fyllandsPosten og OBSERVA i uskøn forening er blevet udstedt et uforståeligt og ugyldigt forbud, gående ud på at forskere i videnskabeligt øjemed hverken må citere Fyllands-Postens artikler i deres helhed eller i form af uddrag, enkeltresultater eller tendenser. Dette indgreb i ytringsfriheden var endnu ikke blevet udtænkt i 1973 Det er næppe heller grunden til, at Risbjerg Thomsen har valgt at henlægge sin validitetstest til denne periode. Min kritik på dette punkt går ud på, at Risbjerg Thomsen har valgt at benytte sig af den vandringsmatrice, der blev offentliggiort i Fyllands-Posten d. 21 . november 1973, jfr. forfatterens litteraturliste. Hvad er det for én? Er det den, der blev offentliggiort d. 22. november, og som sammenlignede stemmeafgivningen ved 1971-valget med stemmeintentionerne pr. 14. november 1973? Uden et større beregningsarbejde vil jeg ikke kunne afgøre det, og det er heller ikke pointen. Pointen er, at Risbjerg Thomsen har valgt 
at benytte et materiale, der i tid er fjernet så langt fra valgtidspunktet, at det ikke giver megen mening at benytte det $i$ en validitetstest, dets indsamlingsmæssige og stikprøvemæssige kvalitet eller mangel pả samme iøvrigt ufortalt. Det foreligger rimelig velbelyst fra en række kommercielle undersøgelser, at der foregik endda voldsomme skift i partiernes styrke just i den skarpe valgkamp op til valget d. 4. december 1973 (Worre, 1976a: 41) - og det plejer jo at indicere større bruttobevægelser blandt vælgerne. Usædvanligt mange vælgere besluttede sig iøvrigt forst i de sidste dage inden valget (Worre, 1976a: 40 og 36). Under disse omstændigheder burde Risbjerg Thomsen i det mindste have benyttet de OBSERVAmaterialer, der blev indsamlet d. 21. november og publiceret d. 29. november. Bedst ville det have været, om han i fyllands-Posten d. 2. december havde læst om et materiale, der blev indsamlet d. 26 . november, dvs. godt en uge før valget.

Hermed har jeg sandsynliggjort, at Risbjerg Thomsens egen undersøgelse af metodens validitet ikke lever op til rimelige krav. Han har sammenlignet sine egne beregnede vælgerbevægelighedstal med to materialer, der næppe fortjener at blive kaldt andet end skyggebilleder af de "sande " bevægelser i vælgerskaren 1971-73. Når han på grundlag af sine sammenligninger konkluderer, at validiteten af de økologiske estimater er på samme niveau som validiteten af interviewundersøgelserne (s. 86 og s. 117), er det en konklusion, der ikke validerer hans egen metode.

\section{Mere om metodens validitet}

Da OBSERVAs vælgervandringsundersøgelser påberåbes i Risbjerg Thomsens afhandling som sammenligningsgrundlag, og da der fra dette firma faktisk foreligger en større serie af vandringsmatricer, alle publiceret i dagbladet fyllandsPosten, kan det her være på sin plads at se lidt nærmere på dette materiale.

Risbjerg Thomsen har selv benyttet materialet fra 1971-73. Jeg har derfor i stedet valgt at starte med nogle observationer fra en mere "stille" periode, nemlig perioden 1975-77, og har valgt at sammenligne nogle efter mit skøn relevante nøgletal. Mens Risbjerg Thomsen i sine validitetstests ganske rimeligt sammenligner totale vandringsmatricer, har jeg nøjedes med noget mindre omfattende, men derfor ikke mindre teoretisk relevant, nemlig sammenligninger af estimater for andelen af stabile vælgere. Det er velkendt, at journalister og politikere interesserer sig mere for de ustabile vælgere og deres mere eller mindre dramatiske bevægelser mellem partierne. Politologer, og her især partisystemforskere, vil i stedet ofte hæfte sig ved graden af stabilitet i de enkelte partiers vælgerkorps og i den samlede vælgermasse. Et simpelt overblik over stabiliteten i det danske vælgerkorps kan således fås ved at studere værdierne $\mathrm{i}$ "diagonalen « $\mathrm{i}$ en vandringsmatrice. Af en god estimeringsmetode, den være sig baseret i survey-metodik eller i økologisk inferens-metode, må man kunne forlange rimelig præcision $\mathrm{i}$ » forudsigelsen " af netop disse værdier, der for de fleste teoretiske formål er mere interessante end de infinitesimale bevægelser til og fra småpartier på de ideologiske fløje i partisystemet.

Tabel 1 viser andelen af stabile vælgere i de enkelte partier ved folketingsvalget d. 15. februar 1977, opgjort henholdsvis efter Risbjerg Thomsens metode og af 
OBSERVA. For yderligere at illustrere problemerne omkring opgørelsestidspunktet er vist to OBSERVA-materialer, nemlig dels tal fra et prøvevalg d. 31 . januar 1977 og dels tal fra selve valgdagen.

Tabel 1. Andelen af stabile vælgere i de enkelte partier ved folketingsvalget d. 15 . februar 1977. Tre opgørelsesmåder.

\begin{tabular}{lccc}
\hline PARTI & $\begin{array}{c}\text { Risbjerg Thomsens estimater } \\
\text { (uden decimal) }\end{array}$ & $\begin{array}{c}\text { OBSERVAs estimater } \\
\text { (prøvevalg) }\end{array}$ & $\begin{array}{c}\text { OBSERVAs estimater } \\
\text { (valget) }\end{array}$ \\
\hline SD & 91 & 90 & 92 \\
V & 47 & $60^{\star}$ & 47 \\
KF & 75 & 76 & 80 \\
RV & 44 & $58^{\star}$ & $37^{\star}$ \\
FRP & 64 & $84^{\star}$ & $81^{\star}$ \\
SF & 45 & $67^{\star}$ & 41 \\
KrF & 53 & 52 & $44^{\star}$ \\
CD & 64 & 61 & 61 \\
DKP & 56 & $66^{\star}$ & $73^{\star}$ \\
DR & 47 & $64^{\star}$ & $69^{\star}$ \\
VS & 68 & $64^{\star}$ & 63 \\
\hline
\end{tabular}

Kilder: Risbjerg Thomsen (1987: 184 - Table 21. D); Fyllands-Posten, 6.2.1977; Fyllands-Posten, 6.3.1977.

Note 1: Tabellens værdier angiver den andel af partiets vælgere 1975, der fastholdt deres partivalg i 1977.

Note 2: " ${ }^{\star}$ ud for et tal viser, at det afviger mere end 5 pct. fra Risbjerg Thomsens estimat i første kolonne.

Et blik på de tre bud på "sandheden « viser ganske betydelige forskelle. Efter min opfattelse er det ikke heldigt, hvis man skal vælge mellem estimater, der afviger ikke bare 5 pct. fra hinanden, men i flere tilfælde en snes procent. Det er ikke muligt at se, om der er tale om systematisk bestemte forskelle. For eksempel er der stort set lige store diskrepanser mellem de to sæt OBSERVA-tal på den ene side og Risbjerg Thomsens estimater på den anden. Noget tyder dog på, at det især kniber med at komme overens om estimaterne for de mindre partier. Interessant er det, at der findes en rimelig overensstemmelse mellem Risbjerg Thomsens estimater og OBSERVAs valgdags-gæt for så vidt angår de større og/eller ældre partier. Men tabellen efterlader dog én med valget mellem, hvem man vil tro pá, og her kan man ikke fã nogen vejledning. Som sagt foreligger der også den mulighed, at begge gæt er fejlgæt $\mathrm{i}$ et større og ukendt omfang, - skyggebilleder blev det kaldt ovenfor.

Sammenligningen mellem Risbjerg Thomsens estimater og OBSERVAs tal fortjener at blive ført videre, for der kunne jo foreligge særlige omstændigheder i såvel 1973 og 1977, som gør én af de to metoder, ja, måske dem begge, ustabil. Derfor er i tabel 2 foretaget en sammenligning af de to sæt estimater over de fire valgperioder, som Risbjerg Thomsens fortræffelige appendix 2 tillader: 
Tabel 2. Forskelle på andelen af stabile vælgere i de enkelte partier, som beregnet af Risbjerg Thomsen og af OBSERVA. Fire valgperioder. Procentdifferencer, opdelt i tre grupper.

\begin{tabular}{|c|c|c|c|c|}
\hline PARTI & $71-73$ & 73.75 & $75 \cdot 77$ & $77-79$ \\
\hline vS & $\star \star$ & * & - & * \\
\hline DKP & $\star \star *$ & - & * & $\star \star$ \\
\hline SF & $\star$ & * & $\star \star *$ & $\star$ \\
\hline SD & $\star \star$ & * & - & - \\
\hline $\mathrm{CD}$ & n.a. & $\star \star *$ & - & * \\
\hline RV & $\star$ & $* *$ & * & * \\
\hline DR & - & $\star *$ & * & $\star \star$ \\
\hline $\mathrm{KrF}_{\mathrm{rF}}$ & $\star \star *$ & $\star \star *$ & - & $\star \star$ \\
\hline V & * & $\star \star$ & * & $\star$ \\
\hline $\mathrm{KF}$ & $\star \star$ & $\star \star$ & - & - \\
\hline FRP & n.a. & $\star$ & $\star \star$ & * \\
\hline
\end{tabular}

Kilder: Risbjerg Thomsen (1987: Appendix 2, tables 19D, 20D, 21D og 22D); Fyllands-Posten 2.12.1973; 8.1.1975; 6.2.1977; og 17.6.1979.

Note: " -" betyder at procentdifferencen (dvs. forskellen mellem Risbjerg Thomsens estimat og OBSERVAs sidste forudsigelse inden valget) er mindre end 5 pct.

${ }^{*}{ }^{\star}$ betyder at procentdifferencen er mellem 5 og 20 pct.

"** " betyder, at procentdifferencen er større end $20 \mathrm{pct}$.

Forskellene (procentdifferencerne) mellem Risbjerg Thomsens estimater og OBSERVAs sidste forudsigelser inden valget er ganske betydelige, som det kan ses. Sat på procenter er det kun 20 pct af alle forudsigelser ( 9 tilfælde ud af 44 ), der viser en rimelig overensstemmelse, defineret som en forskel, der er mindre end 5 pct. I godt en tredjedel af tilfældene er uoverensstemmelsen endda større end 20 pct. Igen kniber det med at spore en systematisk forskel mellem de to datasæt.

Man kan naturligvis ikke ud fra denne påvisning af visse forskelle drage den konklusion, at Risbjerg Thomsens estimater er forkerte og hans metode derfor kassabel. Man kunne med lige sả god - eller lige så dårlig - ret sige, at OBSERVAs tal er helt hen i vejret. Og der foreligger endelig den mulighed, at begge parter rammer ganske meget ved siden af. Et burde stå fast: såfremt det ved de tests, der allerede er i gang og som også i fremtiden vil blive foretaget rundt omkring i Europa, hvor egnede datamaterialer forefindes, skulle vise sig, at Risbjerg Thomsens metode til økologisk inferens kan honorere rimelige krav og dermed opnå forbedret validitetsstatus, da burde det give anledning til alvorlige overvejelser hos OBSERVA - men sảmænd også pả Fyllands-Postens redaktion....

\section{Om metodens anvendelighed og nytte}

Om end det må siges, at der er et stykke vej, inden man kan tillade sig at stole på Risbjerg Thomsens resultater, herunder naturligvis specielt hans i tid "bagudrettede" estimationer af den danske vælgeradfærd 1920-79, sả mả det ogsả fastslås, 
at han, hvis metoden holder, hvad den lover, har bibragt forskningen et uvurderligt materiale, som vil kunne nyttiggøres i mange sammenhænge.

Da Risbjerg Thomsen ikke selv har gjort så meget ud af anvendelsesaspektet, kan der være grund til at knytte nogle få bemærkninger hertil - også fordi der derved måske kan gives et lille bidrag til validitetsdiskussionen. Hvis nemlig anvendelsen af Risbjerg Thomsens estimerede tal, når de bliver brugt $\mathrm{i}$ andre forbindelser, giver rimelige resultater, da er dette i sig selv med til at validere metoden, om end nok så indirekte.

Man har længe "vidst «, at vælgerbevægeligheden er større i de små partier end i de store. Sammenhængen kan spores i de eksisterende OBSERVA-materialer, hvor ikke mindst Centrumdemokraterne (CD) gentagne gange har vist sig at have et yderst flygtigt vælgerkorps. Også i 1970ernes vælgerundersøgelser blev det konstateret, at de nyere - som regel mindre - partier har et løsere vælgerunderlag end de ældre og større partier (Worre, 1976a: $27 \mathrm{ff}$.). Borre (1980) har sandsynliggjort, at ændringer i den aggregerede vælgerflygtighed er forbundet med fremkomsten af nye alternativer for vælgerne, læs: nye partier. På et omfattende europæisk materiale er det blevet vist, at der eksisterer en ret nøje sammenhæng mellem ændringer i aggregeret vælgerflygtighed og ændringer i partisystemets format, det være sig i retning af flere eller færre partier - en sammenhæng, der selvfølgelig igen mả tolkes som forbundet med variationer i partiernes vælgerstabilitet (Pedersen, 1979; 1983).

Hvad kan Risbjerg Thomsens data sige om dette problemkompleks? Tabel 3, der gengiver fire sæt estimater, kan anskueliggøre, hvorledes den økologiske inferens kan være til nytte for partisystemforskningen.

Tabel 3. Sammenhængen mellem partiernes størrelse og stabiliteten i deres vælgerkorps. Pct. kernevælgere, ifølge Risbjerg Thomsen.

\begin{tabular}{lllll}
\hline PARTISTØRRELSE (s) & 1973 & 1975 & 1977 & 1979 \\
\hline Urepræsenteret $(\mathrm{s}<2$ pct.) & VS: 44 & DR: 36 & -- & DKP: 24 \\
\hline $\mathrm{s}<5$ pct. & DKP: 29 & DKP: 55 & DKP: 56 & VS: 75 \\
& DR: 21 & VS: 68 & VS: 68 & DR: 44 \\
& KrF: 80 & CD: 21 & SF: 45 & CD: 26 \\
& & & RV: 44 & KrF: 66 \\
& & & DR: 47 & \\
& & & KrF: 53 & \\
\hline $5<s<15$ pct. & SF: 38 & SF: 54 & V: 47 & SF: 56 \\
& RV: 69 & RV: 57 & CD: 64 & RV: 82 \\
& V: 67 & V: 94 & KF: 75 & V: 72 \\
& CD: - & KrF: 82 & FRP: 64 & KF: 85 \\
& KF: 48 & KF: 50 & & FRP: 56 \\
& FRP: - & FRP: 66 & & \\
\hline s $>15$ pct. & SD: 63 & SD: 91 & SD: 91 & SD: 86 \\
& & V: 94 & & \\
\hline
\end{tabular}

Kilde: Risbjerg Thomsen (1987: Appendix 2, tables 19D, 20D, $21 \mathrm{D}$ og 22D). 
Tabellen kan tale for sig selv, men for sammenfatningens skyld blot dette: mens andelen af "kernevælgere", dvs. vælgere, der stemte pă partiet ved to på hinanden følgende valg (hvilket er en almindelig brugt, om end diskutabel definition af begrebet "kernevælger ") udgjorde 85 pct. i de "store" partier med over 15 pct. af stemmerne, var andelen 65 pct. i de mindre, og kun 50 pct. i de helt små repræsenterede partier; i de urepræsenterede partier var den sả lav som 35 pct. I og med at Risbjerg Thomsens estimater sảledes støtter og mảske endda tydeliggør tidligere, teoretisk baserede observationer, får den nye metode til økologisk inferens øget validitet.

Risbjerg Thomsen peger i sin fremstilling selv på, at andelen af kernevælgere/stabile vælgere har ændret sig over tid, og at den faldt stærkt i begyndelsen af 1970erne. Med en anden terminologi er dette det samme som at sige, at den individuelle vælgerflygtighed øgedes, og en sådan ændring i partisystemets tilstand vil som bekendt oftest, men ikke nødvendigvis, være ledsaget af en tilsvarende øgning i nettobevægelserne i stemmetallene, den aggregerede valgerflygtighed, som denne størrelse er blevet kaldt (Pedersen, 1980; 1983). Via denne sidste storrelse lader den individuelle vælgerflygtighed sig ogsả teoretisk forbinde med mange andre væsentlige aspekter af parti- og repræsentationssystemet (Pedersen, 1984). Alene af denne grund er det en væsentlig opgave at bestemme, hvorledes det statistiske forhold egentlig er mellem de to flygtighedsmäl. Vi ved - og dette er just kernen i problematikken omkring den økologiske fejlslutning - at de to størrelser ikke nødvendigvis er lineært forbundne: ligesom man ikke med logisk gyldighed fra en øgning i bruttobevægelserne kan slutte sig til en øgning i nettobevægelserne, således kan man heller ikke slutte den anden vej. Men en empirisk sammenheng or der nu alligevel, og den er mảske i mange tilfælde tilnærmet lineær? På det danske survey-materiale 1971-81 har Ole Borre i hvert fald konstateret en forbavsende stærk samvariation mellem de to tidsrækker $(r=0,92)$ og han fastslog ogsả følgende: "the regression coefficient indicates that around three quarters of gross vote switching materialises on the macro level as electoral volatility " (Borre, 1985: 381). Hvis man for den lidt længere periode 1947-79 undersøger den statistiske samvariation mellem Risbjerg Thomsens estimerede værdier for individuel vælgerflygtighed (SRTest. = den reciprokke værdi af tallene for vælgerstabilitet, s. 87) og de kendte værdier for den aggregerede vælgerflygtighed, (Agg. Vol.) finder man følgende sammenhæng:

$$
\text { Agg. Vol. }=0,74 \times \text { SRTest }-2,69 \text {, }
$$

med en så høj korrelationskoefficient som: $r=0,94$.

Ligheden med den af Ole Borre fundne sammenhæng er så stærk, at man let kunne finde på at betragte denne observation som endnu et stærkt indicium for, at Risbjerg Thomsens metode besidder validitet. Inden man drager denne konklusion, bør man for det første dog tænke på, at Ole Borres beregninger hviler på et datasæt, der med hensyn til data fra valget i 1973 er statistisk tvivlsomt, jfr. de tidligere bemærkninger herom. For det andet bør man i dette som i Ole Borres tilfælde være opmærksom pá, at det i enhver henseende atypiske 1973-valg har 
en tendens til at sætte sit præg på enhver beregning af statistisk samvariation, jfr. hertil figur 1, som grafisk anskuèliggør den i ovenstående ligning fremstillede statistiske samvariation.

Figur 1. Den statistiske sammenhæng mellem individuel vælgerbevægelighed (SRTest.) og aggregeret vælgerflygtighed (Agg.Vol.)

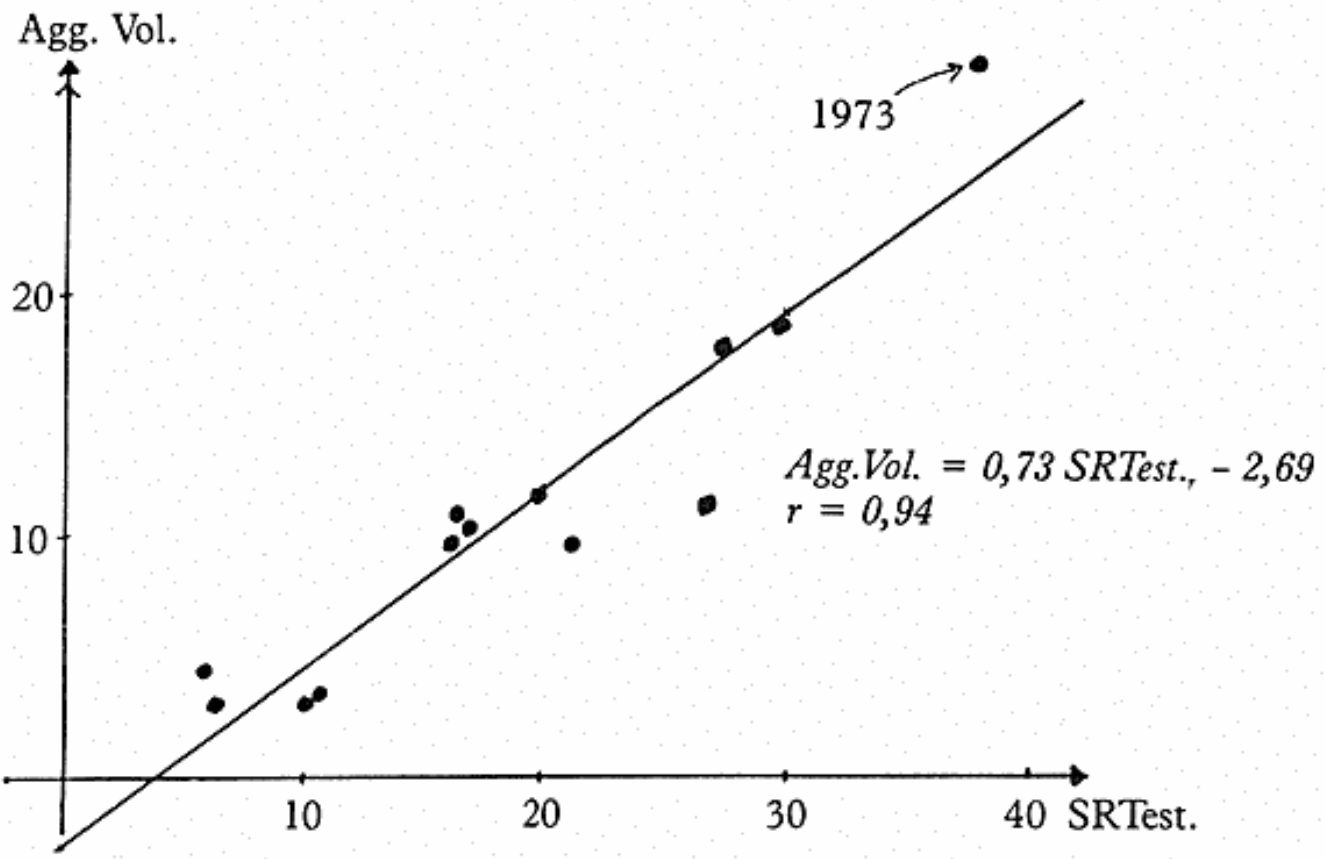

Kilder: SRTest.: Risbjerg Thomsen (1987 s. 87, table 1.3);

Agg.Vol.: Egne beregninger (MNP).

Endelig er det vigtigt at erindre sig, at Risbjerg Thomsen når frem til sine estimater gennem statistisk manipulation af de valgdata, der ogsả danner grundlag for beregningen af den aggregerede vælgerflygtighed. Da de to statistiske størrelser i ovenstående regressionsligning (og i fig. 1) har en fælles baggrund i eksisterende aggregeret valgstatistik, bør man nok være varsom med at benytte den konstaterede samvariation som et alt for tungtvejende indicium for den økologiske inferens-metodes validitet. Problemet med skyggebillederne er også med os her.

Men observationen er interessant, også fordi den antyder noget om, hvad man kan håbe at fả ud af valide økologiske inferens-estimater fra forskellige politiske systemer og fra forskellige tider - nemlig bedre kvantitativ forståelse af det centrale spørgsmảl om partisystemets grad af responsivitet på bevægelser $\mathrm{i}$ vælgerskaren. Er det for eksempel muligt, at der i partisystemer med et givet format (i Sartoris betydning (1976: 128), jfr. ogsả Pedersen (1983: 59-60)) findes et forholdsvis konstant forhold mellem brutto- og nettobevægelser i vælgerskaren? Og for nu at omsætte problemstillingen til den politologiske ingeniørkunsts sprogbrug: er det muligt at nå frem til holdbare beregninger af, hvor store bruttobevæ- 
gelser, der skal til, eventuelt skabes, såfremt man ønsker at nå bestemte mål med hensyn til nettobevægelser, for eksempel ændrede flertalsmuligheder?

Det er ogsả i kraft af de implicitte muligheder og løfter, at Søren Risbjerg Thomsens afhandling er et pionerarbejde, der vil forblive på dagsordenen. Lad os krydse fingrene for, at metoden holder, hvad den lover!

\section{Litteratur}

Borre, Ole (1980). „Electoral Instability in Four Nordic Countries «, Comparative Political Studies, vol. 13, pp. 141-71.

Borre, Ole (1985). „Denmark«, pp. 372-412 i Crewe, Ivor \& David Denver, (eds.) Electoral Change in Western Democracies, London: Croom Helm.

Borre, Ole \& Jan Stehouwer (1970). Fire folketingsvalg 1960-68, Aarhus: Akademisk Boghandel.

Downs, Anthony (1957). An Economic Theory of Democracy, New York: Harper \& Row Publishers.

Eijk, Cees van der \& B. Niemöller (1983). Electoral Change in the Netherlands, Amsterdam: CTPress.

Friedman, Milton (1953). «The Methodology of Positive Economics«, i Essays in Positive Economics, Chicago: Chicago University Press.

Hansen, Jørgen Christian (1987). Danske Valgeres Stabilitet/Ustabilitet i 70erne, Aarhus: Institut for Statskundskab. Utrykt speciale.

Lassen, Aksel (1967). Velgere pá vandring. Nordiske valg 1947-66, Aarhus: Skrifter udgivet af Jysk Selskab for Historie.

Lassen, Aksel (1968). wEndnu et valg ж, Historie, Ny Rakke 8, pp. 98-130.

Noack, J.P. (1981). *Aktuelle vælgerundersøgelser i historisk belysning. Tre bøger om danske valg 1960-1975\%, Historie, Ny Række 13, pp. 151-84.

Pedersen, Mogens N. (1967). wValgforklaringer. Kommentarer til Aksel Lassen: Vælgere pá vandring «, Historie, Ny Række 7, pp. 595-614.

Pedersen, Mogens N. (1979). wThe Dynamics of European Party Systems: Changing Patterns of Electoral Volatility «, European fournal of Political Research, vol. 7, pp. 1-26.

Pedersen, Mogens N.(1980). "On Measuring Party System Change: A Methodological Critique and a Suggestion «, Comparative Political Studies, vol. 12, pp. 387-403.

Pedersen, Mogens N. (1983). »Changing Patterns of Electoral Volatility in European Party Systems, 1948-1977: Explorations in Explanation«, pp. 29-66 i Daalder, Hans \& Peter Mair (eds.), Western European Party Systems. Continuity $\mathcal{E}^{\circ}$ Change, London \& Beverly Hills, Calif.: Sage Publications, Ltd.

Pedersen, Mogens N. (1984). „Vælgerbevægelighed og politisk rekruttering: nogle spekulationer og nogle foreløbige resultater ", pp. 60-85 i Berg, Ole \& Arild Underdal, (red.), Fra valg til vedtak, Oslo: Aschehoug.

Robinson, W.S. (1950). "Ecological Correlations and the Behavior of Individuals", American Sociological Review, vol. 15, pp. 351-57.

Sartori, Giovanni (1976). Parties and Party Systems. A Framework for Analysis. Volume I, Cambridge: Cambridge University Press.

Worre, Torben (1976a). «Partistabilitet og vælgervandringer «, pp. 9-49 i Borre, Ole et al., Valgere i $70^{\prime}$ erne, København: Akademisk Forlag.

Worre, Torben (1976b). „Valgundersøgelsen. Materialets tilblivelse «, pp. 253.55 i Borre, Ole et al. Valgere i 70'erne, København: Akademisk Forlag.

Zetterberg, Hans L. (1965). On Theory and Verification in Sociology, 3. enl. ed., Totowa, N.J.: The Bedminster Press. 
gelser, der skal til, eventuelt skabes, såfremt man ønsker at nå bestemte mål med hensyn til nettobevægelser, for eksempel ændrede flertalsmuligheder?

Det er ogsả i kraft af de implicitte muligheder og løfter, at Søren Risbjerg Thomsens afhandling er et pionerarbejde, der vil forblive på dagsordenen. Lad os krydse fingrene for, at metoden holder, hvad den lover!

\section{Litteratur}

Borre, Ole (1980). „Electoral Instability in Four Nordic Countries «, Comparative Political Studies, vol. 13, pp. 141-71.

Borre, Ole (1985). „Denmark«, pp. 372-412 i Crewe, Ivor \& David Denver, (eds.) Electoral Change in Western Democracies, London: Croom Helm.

Borre, Ole \& Jan Stehouwer (1970). Fire folketingsvalg 1960-68, Aarhus: Akademisk Boghandel.

Downs, Anthony (1957). An Economic Theory of Democracy, New York: Harper \& Row Publishers.

Eijk, Cees van der \& B. Niemöller (1983). Electoral Change in the Netherlands, Amsterdam: CTPress.

Friedman, Milton (1953). «The Methodology of Positive Economics«, i Essays in Positive Economics, Chicago: Chicago University Press.

Hansen, Jørgen Christian (1987). Danske Valgeres Stabilitet/Ustabilitet i 70erne, Aarhus: Institut for Statskundskab. Utrykt speciale.

Lassen, Aksel (1967). Velgere pá vandring. Nordiske valg 1947-66, Aarhus: Skrifter udgivet af Jysk Selskab for Historie.

Lassen, Aksel (1968). wEndnu et valg ж, Historie, Ny Rakke 8, pp. 98-130.

Noack, J.P. (1981). *Aktuelle vælgerundersøgelser i historisk belysning. Tre bøger om danske valg 1960-1975\%, Historie, Ny Række 13, pp. 151-84.

Pedersen, Mogens N. (1967). wValgforklaringer. Kommentarer til Aksel Lassen: Vælgere pá vandring «, Historie, Ny Række 7, pp. 595-614.

Pedersen, Mogens N. (1979). wThe Dynamics of European Party Systems: Changing Patterns of Electoral Volatility «, European fournal of Political Research, vol. 7, pp. 1-26.

Pedersen, Mogens N.(1980). "On Measuring Party System Change: A Methodological Critique and a Suggestion «, Comparative Political Studies, vol. 12, pp. 387-403.

Pedersen, Mogens N. (1983). »Changing Patterns of Electoral Volatility in European Party Systems, 1948-1977: Explorations in Explanation«, pp. 29-66 i Daalder, Hans \& Peter Mair (eds.), Western European Party Systems. Continuity $\mathcal{E}^{\circ}$ Change, London \& Beverly Hills, Calif.: Sage Publications, Ltd.

Pedersen, Mogens N. (1984). „Vælgerbevægelighed og politisk rekruttering: nogle spekulationer og nogle foreløbige resultater ", pp. 60-85 i Berg, Ole \& Arild Underdal, (red.), Fra valg til vedtak, Oslo: Aschehoug.

Robinson, W.S. (1950). "Ecological Correlations and the Behavior of Individuals", American Sociological Review, vol. 15, pp. 351-57.

Sartori, Giovanni (1976). Parties and Party Systems. A Framework for Analysis. Volume I, Cambridge: Cambridge University Press.

Worre, Torben (1976a). «Partistabilitet og vælgervandringer «, pp. 9-49 i Borre, Ole et al., Valgere i $70^{\prime}$ erne, København: Akademisk Forlag.

Worre, Torben (1976b). „Valgundersøgelsen. Materialets tilblivelse «, pp. 253.55 i Borre, Ole et al. Valgere i 70'erne, København: Akademisk Forlag.

Zetterberg, Hans L. (1965). On Theory and Verification in Sociology, 3. enl. ed., Totowa, N.J.: The Bedminster Press. 